\title{
O papel da esposa no Brasil e em Portugal na década de 1930: sua representação nos romances A mulher que fugiu de Sodoma e Ana Paula
}

\author{
Antony Cardoso Bezerra [1]
}

\begin{abstract}
Resumo
Como representação ficcional da realidade, o romance, sobretudo o do modo realista, não está alheio à conjuntura histórica em que é produzido e de que se ocupa. À luz dessa condição, investiga-se, em cotejo, como os romances A mulher que fugiu de Sodoma (1931), do escritor brasileiro José Geraldo Vieira, e Ana Paula (1938), do romancista português Joaquim Paço d'Arcos, abordam uma questãochave de seu mundo: a desestruturação de um casamento em decorrência do comportamento desregrado do marido e, em face disso, o papel desempenhado pela esposa. Com recorrência a estudos sobre representação de Erich Auerbach e de Roger Chartier, bem como sobre a mulher e o casamento, como os de Mary del Priore, Anália Cardoso Torres e Irene Vaquinhas, leem-se as narrativas literárias criticamente, atentando para sua inserção histórica. Enquanto Vieira apresenta, com Lúcia, uma agência no abandono físico do marido, Paço d'Arcos elabora Ana Paula como uma esposa que até à ruína permanece com a consorte.
\end{abstract}

Palavras-chave: condição da mulher nos anos 1930; José Geraldo Vieira; Joaquim Paço d’Arcos.

The role of wife in Brazil and Portugal at the 1930s: Its representation in A mulher que fugiu de Sodoma and Ana Paula

\begin{abstract}
The realist novel, more than other modes of fictional representation, relates to the historical conjoncture where is produced and which it focuses. By considering that condition, this paper investigates and compares the novels A mulher que fugiu de Sodoma (1931), by Brazilian writer José Geraldo Vieira, and Ana Paula (1938), by Portuguese novelist Joaquim Paço d'Arcos, regard an important issue of their world: a marriage wreck due a vile behaviour of husbands and the resulting role played by wifes. Based on studies by Erich Auerbach and Roger Chartier about representation and on investigations by Mary del Priore, Anália Cardoso Torres and Irene Vaquinhas about women and marriage, literary narratives are critically approached, considering also their historic inserction. Whereas Vieira presents the agency of Lúcia, who leaves her husband, Paço d'Arcos builds Ana Paula as a wife who stays with her spouse untill his breakdown.
\end{abstract}

Keywords: women's condition at the 1930s; José Geraldo Vieira; Joaquim Paço d'Arcos.

Le rôle de l'épouse au Brésil et au Portugal dans les années 1930: sa représentation dans les romans A mulher que fugiu de Sodoma et Ana Paula

\section{Résumé}

Le roman réaliste, plus que d'autres modalités de représentation fictionnel, établit un rapport avec le conjoncture historique où est produit et qui est couverte par celui-ci. En considérant la condition de la femme, cet article étudie et compare les romans $A$ mulher que fugiu de Sodoma (1931), par l'écrivain brésilien José Geraldo Vieira, et Ana Paula (1938), par le romancier portugais Joaquim Paço d’Arcos, en se concentrant dans un élément important de leur monde : la destruction d'un mariage en raison du comportement ignominieux des maris et, en conséquence, le rôle joué par les épouses. Basé sur des études réalisées par Erich Auerbach et Roger Chartier sur la représentation aussi bien que sur la recherche développée par Mary del Priore, Anália Cardoso Torres et Irene Vaquinhas sur les femmes et le mariage, les récits littéraires sont abordés de façon critique dans leur inserction historique. Tandis que Vieira présente le comportement actif de Lúcia, qui quitte son mari, Paço d'Arcos construit Ana Paula comme une femme qui reste avec son mari jusquâ la fin.

Mots-clés: la condition de la femme à les années 1930 ; José Geraldo Vieira ; Joaquim Paço d'Arcos.

El papel de la esposa en Brasil y en Portugal en la década de 1930: su representación en las novelas A mulher que fugiu de Sodoma $y$ Ana Paula

\section{Resumen}

La novela, una representación ficticia de la realidad, especialmente en su forma realista, no se aleja al contexto histórico en que se produce y que trata. A la luz de esta condición, se hace una lectura paralela de las novelas A mulher que fugiu de Sodoma (1931), de lo escritor brasileño José Geraldo Vieira, y Ana Paula (1938), de lo novelista portugués Joaquim Paço d’Arcos, en la representación de un problema clave de su mundo: la desintegración de un matrimonio debido al mal comportamiento de los maridos y la reacción de las esposas. Teniendo en cuenta los estudios sobre representación, de Erich Auerbach y Roger Chartier, y sobre las mujeres y el matrimonio (p. ej. Mary del Priore, Anália Cardoso Torres e Irene Torres), se hace un examen crítico de las narrativas literarias en su inserción histórica. Mientras Vieira presenta el carácter activo de Lucía, en el abandono físico del marido, Paço d'Arcos elabora Ana Paula como una esposa que está con su marido hasta el final.

Palabras-clave: la situación de la mujer en la década de 1930; José Geraldo Vieira; Joaquim Paço d'Arcos. 

logo alemão Erich Auerbach, Hayden White destaca uma característica da prática hermenêutica desenvolvida na obra resenhada: "Auerbach tende a 'apresentar' o texto como uma 'representação' não tanto de seu entorno social, político e econômico, mas também da experiência que o autor tem deste entorno [...]" (White, 2005, p. 309). Dentro da proposição figural ${ }^{2}$ do erudito germânico, a obra literária dá conta de seu ambiente - independentemente do modo ficcional por que se configure - em um enviesamento derivado da intervenção do escritor que a produz. Nesse sentido, o que o romancista francês Honoré de Balzac disse acerca do gênero romance, contrapondo-o ao discurso histórico produzido a seu tempo, parece fazer sentido, com todas as licenças que o enunciado possa merecer - a narrativa ficcional seria capaz de fixar uma "história esquecida por tantos historiadores, a dos costumes" (Balzac, 1949, p. 12). Com quase um século de antecedência à chamada nova história francesa, o escritor suscita duas tendências que só posteriormente ganharão corpo: a história social e a história imediata (ou da atualidade). Não se deseja aqui cometer a leviandade de atribuir a Balzac a condição de precursor de práticas historiográficas que ascenderam e se desenvolveram no século XX; antes, intenta-se mostrar como o discurso ficcional também é capaz de descortinar um mundo traduzido por uma individualidade produtora dentro daquilo que Segismundo Spina chamou de atividade transcendente da filologia, qual seja, a de, a partir de um texto, "reconstruir a vida espiritual de um povo ou de uma comunidade em determinada época” (Spina, 1977, p. 77).

É dentro desse diapasão - insiste-se: da leitura de uma conjuntura histórica em sua transfiguração por meio da individualidade autoral e da ficcionalidade - que a presente investigação se desenvolve. Daí a importância de, ao menos preliminarmente, problematizarem-se as questões atinentes à representação linguístico-ficcional para que, só então, abordem-se mulher e casamento nos romances A mulher que fugiu de Sodoma (1931), do escritor brasileiro José Geraldo Vieira, ${ }^{3}$ e Ana Paula: perfil de uma lisboeta (1938), primeiro

\footnotetext{
2 Detalhada no ensaio Figura e norteadora das análises de Mimesis, a noção de figura conforme trabalhada por Auerbach implica tanto (1) as relações históricas que se estabelecem entre dois textos (em que um é a consumação histórica do que o antecede e, ainda, promessa de manifestações vindouras) quanto (2) a concretização discursiva de uma experiência autoral em dada conjuntura histórica. É essa segunda dimensão que mais intimamente interessa ao presente trabalho. A afirmação da representação figural, conforme o estudioso alemão a concebe, resultaria da escolástica, preocupada em estabelecer ligações históricas (porque concretizáveis na realidade) entre o Antigo e o Novo Testamento. Indique-se que as articulações entre os textos e entre estes e o horizonte histórico não são inerentes; antes, resultam do olhar do analista, capaz de promovê-las.

${ }^{3}$ José Geraldo Vieira nasceu no Rio de Janeiro, em 1897, seguindo uma linhagem de família nobre açoriana. Estreou-se em livro com O triste epigrama (1919), mas é no romance - sendo o primeiro, precisamente, $A$ mulher que fugiu de Sodoma - que se notabiliza, com recorrentes retratos dos desvãos da memória em que a alta burguesia é a comunidade mais recorrente. Formado em medicina e especializado em radiologia algumas de suas personagens centrais serão médicas, como se vê em Território humano (1936), em A ladeira da memória (1950) e no próprio A mulher que fugiu de Sodoma -, Vieira foi um homem cosmopolita, vivendo entre o Rio de Janeiro, São Paulo e a Europa, com um período sabático passado no interior paulista, no município de Marília. É justamente por esses cenários que a maior parte de suas personagens se movimenta, em uma representação dos dramas individuais que são aguçados pela atmosfera do entreguerras, da Segunda Grande Guerra e de seus desdobramentos. Na década de 1940, abandona a atividade médica para atuar apenas como autor literário e tradutor, prática esta que o pôs em contato sistemático com a nata da
} 
da série intitulada "Crônica da vida lisboeta", do autor português Joaquim Paço d'Arcos. ${ }^{4}$ Ainda que se tente situar os romances em sua integralidade, porção fulcral do inquérito ao corpus se dirige aos capítulos em que as personagens das esposas - Lúcia e Ana Paula, respectivamente - decidem abandonar/ seguir o marido de caráter mais que duvidoso. Enfatizam-se, assim, os capítulos 6 (parte 1) de A mulher que fugiu de Sodoma e 6 (parte 2) de Ana Paula.

\section{Narrativa, representação e História}

Em uma investigação acerca do estatuto do discurso historiográfico na modernidade, José Carlos Reis afirma: “Contra [a] narrativa tradicional, a históriaproblema reconhecia a impossibilidade de se narrar os fatos como se passaram" (Reis, 2006, p. 133). Rechaçando a ideia de uma narrativa que se possa chamar de neutra - um mero continente dos dados históricos por si sós, que, nesse caso, seriam considerados o efetivo objeto da história - e a de uma realidade como instância monolítica, essa nova percepção acaba por aproximar o histórico do ficcional, pois ambos se realizam na esfera narrativa, na composição de uma intriga, uma "imitação criadora" da realidade (Reis, 2006, p. 138). Evidentemente que não correspondem as atividades do literato e do historiador em todas as etapas de produção, pois o processo investigativo conduzido por um e por outro diferem em vários aspectos - no mínimo, pelas

literatura ocidental dos séculos XIX e XX. Sobre a obra ficcional de Vieira, disse Alfredo Bosi: "Prosa cortada por transcrições de anúncios luminosos, por nomes de artigos franceses e ingleses e por um sem-número de neologismos, citações eruditas e referências técnicas, ela é uma lente de aumento da linguagem do burguês culto e sofisticado que respira ondas contínuas e crescentes de informação. Mas o seu refinamento vai mais fundo e chega mais longe enquanto molda criaturas extremamente instáveis e nervosas, incapazes de situar e de resolver os seus conflitos fora dos quadros culturais da literatura e da arte, sua segunda e definitiva natureza" (Bosi, 1995, p. 412). O romancista faleceu em São Paulo em 1977. Embora, na atualidade, sejam muito raras as reedições de obras de Vieira, bem como seu público leitor se mostre escasso, existe um trabalho no sentido de recuperar seu legado literário, ressaltando sua posição sui generis no âmbito da literatura brasileira produzida no século XX.

${ }_{4}^{4}$ Joaquim Belford Corrêa da Silva - nome civil de Paço d'Arcos - nasceu em Lisboa, em 1908, e conheceu de perto o poder e os meios aristocráticos, acompanhando o pai em atuação deste no ultramar português, tanto na África quanto na Ásia. Trabalhou em funções burocráticas, mas não buscou formação universitária. Em 1932, vem ao Brasil para trabalhar com antiguidades, logo se frustrando e retornando à terra natal. Dessa experiência resultará o romance Diário dum emigrante (1936), segundo do autor; o primeiro livro, de cenário luso e africano, fora Herói derradeiro (1933). Também memorialista, ensaísta, contista e poeta, é na condição de romancista que Paço d'Arcos faz seu nome na literatura portuguesa do século XX. Reconhecidamente, o ponto alto de sua produção consiste na tentativa de, em pequena escala, fazer pelo Portugal de seu tempo o que Balzac fizera pela França da primeira metade do século XIX (um registro ficcional, e realista, das relações sociais), a "Crônica da vida lisboeta", série de seis romances que contemplam prioritariamente as classes altas da Lisboa de meados do século XX. Trata-se de um mundo que o conservador Paço d’Arcos, alinhado ao regime do ditador Antonio de Oliveira Salazar, conheceu muito proximamente; e, à maneira do mestre francês, faz as personagens cruzarem-se entre as narrativas. O primeiro romance da série é, exatamente, Ana Paula, a que se atribuiu (não sem polêmica) o prêmio "Ricardo Malheiros", da Academia de Ciências, que o autor optou por recusar. Assim José Maria Viqueira Barreiro caracterizou a atuação do literato: "Joaquim Paço d’Arcos tem verdadeira sensibilidade artística com que penetra o mais fundo da dor humana de seu tempo. E dessa penetração traz à luz, também dolorosamente, aquelas formas de arte que respondem a um modo de expressão própria. Porque a preocupação fundamental deste escritor é devolver-nos um mundo reelaborado através de uma sensibilidade personalíssima" (Barreiro, 1958, p. 44; tradução nossa). Falecido em 1979, o autor, detentor de um público considerável quando vivo, cada vez menos desperta o interesse dos leitores - diletantes e, mesmo, da crítica -, muito, ao que parece, por seu comportamento de apoio ao salazarismo. 
contas que têm de prestar das fontes que venham a consultar. De outro lado, cumpre atentar para o fato de que também o discurso histórico desenvolve-se em um plano mimético, haja vista a afirmação de White: “O que se conta na narrativa é uma mimese do enredo vivido em alguma região da realidade histórica, e, tanto quanto seja imitação acurada, é doravante considerada um relato verdadeiro" (White, 2011, p. 442). Não se desejando adentrar os meandros do que "verdade" possa significar no plano da história e da historiografia - sob pena de se seguir por um desvio que pouco útil será para o desenvolvimento deste trabalho —, vêm à tona aqui os procedimentos de pesquisa histórica que devem constituir a base inelutável de uma tal atividade; in nuce, como já se indiciou, o compromisso com o levantamento e com a análise das fontes. Voltando a White: "Na narrativa histórica, os sistemas da produção de sentido peculiares a uma cultura ou sociedade são testados contra a capacidade de qualquer conjunto de eventos 'reais' de ceder a tais sistemas" (White, 2011, p. 467). Em acréscimo a isso, vale ter-se em conta que "a literatura e a poesia [têm] qualquer coisa válida a nos ensinar sobre a realidade" (White, 2011, p. 467). O quadro delineado, que acaba por aproximar as práticas de escrita histórica e ficcional, abre ainda as portas em outro sentido que não o indiciado: o da obra literária como representação possível de dada conjuntura histórica. ${ }^{5}$

Uma das maneiras como essa representação da realidade pode ser equacionada em termos literários consiste no que Auerbach chamou de "realismo sério" (esfera em que, por certo, inscreve-se o corpus deste trabalho): "os acontecimentos mais corriqueiros da realidade num contexto sério mas significativo [...]" (Auerbach, 1976, p. 500). E, no método empregado pelo autor em foco, para além da já referida iluminação de dada conjuntura, afirmam-se como históricas a produção e a recepção (crítica ou diletante) de um texto. A mimese se afirma na medida em que a transfiguração individual de uma realidade é materializada por meio do discurso - preponderantemente o ficcional, em Auerbach, mas não apenas. E vale adicionar: não está em questão, neste passo, a ideia de uma realidade inerente, inexorável; mas, sim, daquela que é reelaborada discursivamente, resultado de uma relatividade que se traduz em várias dimensões: linguística, ideológica, cultural etc. Roger Chartier, à luz dos estudos de Stephen Greenblatt sobre William Shakespeare, parece ter empregado palavras muito precisas para caracterizar esse processo: "A circulação entre o mundo social e as obras estéticas pode apoderar-se de qualquer realidade, tanto dos desejos, das ansiedades ou dos sonhos quanto do poder, do carisma ou do sagrado [...]" (Chartier, 2011, p. 97). O estatuto que, a partir dessa consideração, pode-se atribuir ao romance é o de um gênero literário que representa ficcionalmente certo quadrante histórico em uma amplitude de aspectos que vai das relações sociais aos desvãos da memória, das trocas de valores à formação do indivíduo. Pode-se argumentar que essa concretização

\footnotetext{
${ }^{5}$ Vale ter-se em conta que a abordagem do discurso literário em sua interface com a história não pode desprezar as peculiaridades do estatuto daquele: "A literatura não é simplesmente uma parte da realidade como qualquer outra, apesar de que os historiadores a tratem, às vezes, como tal" (Fowler, 2005, p. 261; tradução nossa).
} 
se faz possível apenas no romance vinculado ao modo realista de produção ficcional - que é bem o caso de A mulher que fugiu de Sodoma e de Ana Paula, já que não contêm a representação de eventos discrepantes da noção de realidade vigente em sua conjuntura - , mas acredita-se que, diferentemente, todo e qualquer modo ficcional (estranho, fantástico ou maravilhoso) resulta de seu mundo, modificando-se apenas a estruturação do imaginário conforme empreendida pelos respectivos autores.

\section{A mulher que fugiu de Sodoma, de José Geraldo Vieira, e Ana Paula, de Joaquim Paço d'Arcos: romances e autores em seu mundo}

Primeiro romance de Vieira, A mulher que fugiu de Sodoma é portador de características que serão encontradas em outras obras do escritor. Do ponto de vista da forma, pode-se apontar a narrativa situada em vários espaços e com não escassas remissões a planos passados, com espécies de analepses que cumprem, com nitidez, sua função: tornar clara a situação presente de uma personagem. No que diz respeito à expressão, está-se diante de uma escrita e de um tom elevados, projeção da própria erudição do autor. Para Luís Bueno, Vieira emprega um

[...] tom mais coloquial no discurso direto, especialmente nas falas de alguns tipos de malandros. Mesmo assim, vez por outra as personagens se tratam por vós, conjugando os verbos como se deve e atentos $[$ sic] à colocação pronominal, o que dá um tom algo artificial a sua prosa. (Bueno, 2006, p. 112)

Para se referendar a condição desse traço como extensiva a outras obras do romancista, é o caso de recorrer a Antonio Candido, segundo quem, em $A$ quadragésima porta (1943), "O estilo é corretíssimo e rebuscadamente trabalhado" (Candido, 2011, p. 39). Dizia-se que A mulher que fugiu de Sodoma irá projetar-se em não poucos sentidos sobre a posterior produção de Vieira, e, no âmbito temático, isso também é verdade. Inicialmente, pode-se pensar no anelo do amor puro, verdadeiro, que, por vicissitudes da existência humana, não se concretiza (ver, por exemplo, A ladeira da memória). Também nos meios por que circulam as personagens, de uma burguesia que não parece conhecer dificuldades materiais, salvo aquelas condicionadas por comportamentos absolutamente desviantes, como é o caso de Mário de Montemor, um dos protagonistas de $A$ mulher que fugiu de Sodoma, indivíduo que se arruína em decorrência de sua paixão desenfreada pela jogatina. Detecta-se, ainda, a movência dos caracteres, que, já por seu berço ou sua condição financeira, vivem entre o Brasil e a Europa, e, segundo Candido (novamente a propósito de A quadragésima porta), também no Brasil como se da Europa tratasse:

[Burguesia litorânea] Que tinha a vocação do cosmopolitismo e o culto da viagem à Europa, donde importava tudo [...]. O livro de José Geraldo Vieira é o mais brilhante sintoma e, porventura, 
a suprema afirmação literária dessa classe sem consciência efetiva, em equilíbrio instável sobre uma economia semicolonial, marginalizada culturalmente por um desejo doentio de participar, custasse o que custasse, das radiações do Ocidente europeu. (Candido, 2011, p. 30)

Trata-se de conjuntura que acaba por evidenciar muito mais os dramas condicionados por buscas individuais que aqueles causados pelos constrangimentos econômicos. Em que pese isso, curiosamente, em $A$ mulher que fugiu de Sodoma é uma circunstância financeira que alimenta o desenvolvimento da história. O médico Mário, casado com Lúcia, é, como já se disse, viciado em jogos de azar, o que o conduz à queda moral e à falta de dinheiro. Portador de 16 contos, pertencentes ao dr. Silva Soares, Mário, que mora no Rio de Janeiro, tem por tarefa comprar equipamentos para a Santa Casa de Rio Preto. Na mesa de jogo, o dinheiro desaparece, e o colega dá um ultimato para que o jogador devolva a quantia, sob pena de este ser denunciado à polícia. Lúcia, depois de penosa peregrinação, consegue auferir a quantia com o sr. Almada, financista e esposo de Ana Maria, uma antiga colega de escola. Salvo do constrangimento, Mário, no entanto, não se liberta do vício e irá, segundo Lúcia, cometer o supremo pecado de abandonar a vida de uma criança - o jornaleiro Segundo Clichê, que padece de meningite - em benefício do jogo; e, mais, ainda aceitará honorários dos humildes pais do garoto morto. A esposa abandona o médico e vai morar com uma tia, Marta (nada mais que remediada). ${ }^{6}$ Depois disso, será preceptora da filha de Ana Maria, e Mário, entre o interior de São Paulo e a Paris convidativa à vida desregrada - de cujo bas fond irá desfrutar —, imergirá cada vez mais em uma existência indigna, até encontrar a morte. No desfecho da narrativa, na consubstanciação de um assédio que já se desenhara anteriormente, Lúcia abandona a casa do sr. Almada, que urdira uma sórdida trama para dispor da preceptora de sua filha. A viúva, assim, converte-se na mulher que fugiu de Sodoma aludida no título do romance. ${ }^{7}$

Ana Paula não é a estreia de Paço d'Arcos em narrativas longas, mas é, conforme já indicado, o primeiro romance da "Crônica da vida lisboeta"; é, também, o primeiro livro do autor cuja diegese está situada exclusivamente em Portugal. Em face da sequência da obra de Paço d'Arcos, a história de Ana Paula e Jorge de Melo carregará muitas marcas que se desdobrarão nos cinco demais romances da série a que pertence. Do ponto de vista estético, a ligação ao modo realista de produção ficcional — na esteira de Eça de Queirós, pode-se dizer, mas deste dispensando certo tom farsesco - é marca que permeará os volumes em questão. $\mathrm{O}$ estilo escorreito e tendente à linearidade de Paço d'Arcos também nasce em Ana Paula e se firma na obra subsequente do autor. O cenário privilegiado é o do Terreiro do Paço lisboeta, espaço em que

${ }^{6}$ Com vagar, adiante, analisam-se a agonia do garoto e o abandono do lar por Lúcia.

${ }^{7} \mathrm{O}$ título da narrativa também se deve, em uma espécie de mise-en-abîme, à referência, feita no corpo do romance, a um estudo de Rubens para o quadro A fuga de Ló; o esboço tem por nome, precisamente, "A mulher que fugiu de Sodoma" (cf. Vieira, 2008, p. 319). Não se deixa de notar, aqui, a erudição de alusões que se encontram na obra do romancista. 
os detentores do status quo se envolvem em grandes questões, mas que, em sua vida privada - permeada por desconfortos, desencontros e traições deparam com não poucos atrapalhos, que se transformam mesmo no combustível da crônica. Tudo isso com um tom marcante, o do já aludido "realismo sério", pois Paço d'Arcos

Não sublinha com uma risada de desprezo ou com um traço de caricatura impiedosa os seus defeitos e os seus erros, mas no-los descreve com os tons nervosos de uma sensibilidade que reage, chocada, diante do espetáculo de certas almas e de certos sofrimentos. (Mendes, 1972, p. 36)

\section{O estatuto que pode-se atribuir ao romance é o de um gênero literário que representa ficcionalmente certo quadrante histórico}

Os descompassos amorosos e as obrigações sociais digladiam-se na alma dos protagonistas da "Crônica da vida lisboeta", em que os pecados da existência privada acabam por repercutir na face pública das personagens. No caso específico de Ana Paula, tem-se a personagem-título como uma mulher aristocrática que se casa com um herói da Primeira Guerra Mundial, o oficial Jorge de Melo. Ele tem uma vida desviante - que passa pela inclinação ao jogo de azar e ao adultério ${ }^{8}-\mathrm{e}$, em suas funções administrativas, acaba por cometer um desfalque. Sua vida de fausto rui quando é descoberto. Ana Paula, impávida, não abandona o marido encarcerado. Eis que entra em cena a terceira personagem central do romance, o advogado Eduardo Reis. Eduardo defende o amigo com afinco, mas enamora-se de Ana Paula, que apenas em seu íntimo corresponde. Constrangida pelas obrigações religioso-sociais (em um termo apenas, católicas), Ana Paula não cede à tentação desenvolvida no triângulo amoroso ${ }^{9} \mathrm{e}$, após a improvável absolvição do marido, segue com este para um autoexílio africano. No escopo da narrativa, a esposa de Jorge é tida - entre as demais personagens e mesmo no olhar do narrador - como exemplar em todos os sentidos, uma mulher superior que sacrifica a felicidade em benefício de um sólido conceito de honra, lastreado pelo voto de fidelidade feito ao marido (que, por seu turno, não atende às obrigações maritais, seja pela desonestidade no trabalho, seja pela relação perniciosa com a cortesã Maria da Graça).

\footnotetext{
${ }^{8}$ Trata-se de dois comportamentos que estão no cerne da dissolução familiar - perspectiva que vigia no ocaso do regime monárquico e que também esteve presente no Estado Novo. No dizer de Vaquinhas, interpolado por remissões à médica e escritora Anna Fisher-Dückelmann - autora, entre outros, de $A$ mulher como médico da família (1913) -, "Tanto o jogador como o alcoólico encarnavam a antítese do bom pai, do trabalhador disciplinado e honesto e, por extensão, do patriota consciencioso, sendo responsabilizado pela 'decadência individual', pela 'miséria e infortúnio' da mulher e filhos, e por comprometerem a descendência e o futuro da espécie" (Vaquinhas, 2011, p. 322).

${ }^{9}$ O capítulo do romance que adiante se detalha põe frente a frente Ana Paula e Eduardo, atados que estão por suas obrigações públicas.
} 
Se o desfecho dos romances, conforme sinalizado nas sinopses apresentadas, é similar no muito pouco alvissareiro destino das protagonistas femininas - Lúcia e Ana Paula - , as atitudes por elas tomadas ao longo das narrativas revelam uma disparidade de comportamento, que, se tem um fundo comum (os valores católicos), conduzem-nas a abordagens distintas do problema que as atormenta: um marido mandrião que não as satisfaz em nenhum sentido que seja. Antes de se chegar ao momento-chave dos romances - que, para os interesses deste trabalho, consiste na separação ${ }^{10}$ de Lúcia e Mário e na continuação dos laços que unem Ana Paula a Jorge - , é o caso de entender em que base se constituem os contratos de casamento, por que espaços sociais circulam as personagens, que comportamentos específicos os maridos revelam e como as esposas lidam com isso.

Tendo-se em conta a atmosfera nada agradável em que se desenvolve o casamento de Lúcia com Mário e o de Ana Paula com Jorge (o único refrigério para esta esposa consistindo no filho Tony), pareceu útil, aos autores dos romances, contrastar a situação presente das duas mulheres com o seu período de formação. ${ }^{11}$ Aristocráticas, ambas gozaram de cuidados condizentes com sua classe, o que é exposto pelos narradores dos romances. Em trechos do capítulo 5 (parte 1) de A mulher que fugiu de Sodoma, tem-se uma Lúcia que, ponderando sobre um possível lado bom de seu marido (o do médico que, supostamente, "passava [noites] à cabeceira de doentes pobres, sem ideia de lucro algum [...].”; Vieira, 2008, p. 87), começa a lembrar-se do noivado e dos primeiros meses do casamento. A recordação fá-la abrir um cofre pessoal, em que "guardava os seus segredos inocentes" (Vieira, 2008, p. 88). O que encontra? "Lembranças de noivado. Presentes. Medalhas. Coisas sem valor, postais, uma Imitação de Cristo toda comentada, ainda do tempo dos salesianos. Uma edição delicada e pequenina dos Mártires do Cristianismo" (Vieira, 2008, p. 88). Vem à tona uma educação cristã (pois que estudou em "colégio de freiras"; (Vieira, 2008, p. 104), de valores que ainda parecem incrustados na mulher que viveu e aprendeu sobre a existência na própria pele, mas que, até aqui, não consegue se rebelar contra o papel cruel que o destino lhe reservou, o de ser a esposa de um homem perdido pelo vício. A memória de Lúcia também recupera a fazenda em que cresceu e da preta que a criou (Vieira, 2008, p. 88-89), o que ajuda a elaborar uma ambiência de nostalgia que se apodera da personagem. Rememora também a convivência com a faustosa e excêntrica marquesa de

\footnotetext{
${ }^{10}$ Embora o problema do divórcio não pareça alheio à discussão empreendida na presente investigação, opta-se por, em termos mais gerais, chamar de separação a descontinuidade de um casamento. Isso se condiciona pela diferença de enfoque da questão nos dois romances. Enquanto em Ana Paula chega a haver um capítulo que discute diretamente a questão - 4 (parte 2): "Do Divórcio: remédio ou causa de males?” -, no livro de Vieira o divórcio, ainda que a mulher deixe o marido, não é problematizado. Em termos englobantes, assim, enfocam-se os papéis sociais desempenhados pelas personagens em contraste com as estruturas mentais que guiam seu comportamento, até pelo receio de se cair em uma discussão de cunho jurídico. (Sobre a relação mulher e casamento sob olhar jurídico, cf. Canezin, 2004.)

"Saliente-se que também a criação de Mário e a de Jorge irão as narrativas descrever, mas, por o foco deste artigo dirigir-se ao papel feminino, optou-se por não se detalharem as informações dos maridos quando mais jovens.
} 
Sincorá, sua sogra, e das traquinices infantis com aquele que seria o marido que tanto a faria penar.

Agora, nesta noite, como em muitíssimas outras, adormecia sozinha, cansada de esperá-lo [Mário]. E, adormecendo, se lembrava da sua babá, da sua ama negra enterrada numa sepultura onde cresciam roseiras que só davam rosas brancas. Anos depois, por falta de pagamento, acabara sendo transferida para a vala comum. (Vieira, 2008, p. 105)

Apresentadas como um paraíso perdido, infância e adolescência parecem tempos ainda mais felizes, pois que em face de um presente permeado apenas por frustrações. Símbolo dessa inocência perdida, o descaso com a cova da velha Nhá Bárbara acaba por revelar o caráter irrecuperável do passado, que não saiu de Lúcia, mas que não passa de uma lembrança que se possa acalentar, uma vez que em nada parecida com o presente de sofrimentos.

Se a representação da formação de Lúcia, pelo narrador de $A$ mulher que fugiu de Sodoma, simula uma contingência fortuita, a de Ana Paula soa mais esquemática no fito de caracterizar a vida prévia de sua personagem-título. De Ana Paula, em sequência, fica-se a saber da "Ascendência", da "Infância", do "Colégio", da "Vida de Solteira" e do "Casamento" (capítulo 1, parte 1). Ana Paula é filha dos condes da Balsa, e pujante é sua genealogia, que remonta ao medievo português (Paço d'Arcos, 1974, p. 97). O narrador faz referência a um fato-chave na história moderna de Portugal - a Proclamação da República de 1910 (Paço d'Arcos, 1974, p. 102) - para dar conta da mudança de status da família de Ana Paula, o que não significará uma decadência moral, pois a nobreza de sangue parece elemento enfaticamente prezado no projeto do romance (e, por que não dizer, do autor, ele mesmo descendente de família dita tradicional). É revelado, ainda, o comportamento indócil da pequena Ana Paula, o que faz seu pai interná-la em um colégio religioso, em que se acordava com a voz clara da freira a dizer "Sejam louvados Jesus e Maria" (Paço d'Arcos, 1974, p. 105). A fé quase singela que se cultivava em casa de Ana Paula cedeu lugar à fé como palavra de lei, o que baterá fundo no caráter da personagem.

[...] apesar de as freiras serem caridosas e da sua tirania ser suave e bem intencionada, o ambiente em que [Ana Paula] se desenvolvia não era propício ao fortalecimento da sua personalidade. No colégio aprendeu a calar sentimentos e a refrear a espontaneidade da sua alma; dele saiu mais bondosa mas mais submissa, menos apta a resistir ao domínio de outrem, mesmo que despótico, porque em penitências e rezas aprendera a submissão, menos preparada para dar batalha à adversidade porque esta é desígnio de Deus e, quando surge, abrigamo-nos com Ele e Ele nos confortará. (Paço d'Arcos, 1974, p. 107)

De criança irrequieta, Ana Paula se converte em jovem contida. É inegável, no projeto do romance, a ênfase que se confere aos constrangimentos que o caráter da personagem sofre tanto da religião quanto da sociedade, sendo a 
temporada escolar talvez a mais marcante no primeiro sentido. Nela, Ana Paula aprende a ser resiliente, comportamento que será o seu ao longo de toda a narrativa, em que recusa a própria felicidade em benefício do sacramento que a uniu a Jorge. Em investigação sobre a sociedade portuguesa de fins do século XIX e princípios do XX, Maria Lúcia de Brito Moura assinala o que chama de "feminização do catolicismo":

Sendo o anticlericalismo [tipicamente republicano] uma manifestação essencialmente masculina, as mulheres constituíam a grande reserva da Igreja Católica, esperando-se que, através delas, não só as novas gerações fossem crescendo dentro dos princípios do catolicismo, mas também os cônjuges, afastados da prática religiosa, a ela regressassem. As mulheres deviam sacrificar-se para conseguir, neste mundo, a felicidade do marido e dos filhos; no outro, a salvação das suas almas. (Moura, 2011, p. 295)

Em certo sentido, o quadro histórico que se pinta está configurado na formação e na práxis de Ana Paula. O artigo indefinido do subtítulo do romance - "perfil de uma lisboeta" - coloca-a em um eixo comportamental genérico, ainda que as vicissitudes, claro, sejam particulares. Também no casamento haverá esse jogo de dupla partida, em que as individualidades se encontram com o conjuntural.

Após introduzida na sociedade - a de Lisboa, que, "no começo dos vinte, [era] um pequeno burgo [...]” (Paço d'Arcos, 1974, p. 108) —, Ana Paula vem a conhecer o herói da Primeira Grande Guerra Jorge de Melo, com quem se casará. Por mais esforços que envidasse por, a partir de seu próprio exemplo, afastar Jorge da vida mundana, Ana Paula não obtém sucesso. O sacrifício de que fala Moura, assim, será vão:

Considerando que o casamento, nas classes superiores, resultava, ainda em boa parte, de ajuste entre famílias, num sem-número de casos ainda existia um profundo fosso entre os membros do casal quanto a crenças e comportamentos de feição religiosa. À mulher só restaria rezar pelo marido e tentar evitar que os filhos seguissem as pisadas do pai. (Moura, 2011, p. 296)

Toda iniciativa da religiosa Ana Paula para poupar o filho, Tony, dos desgastes ocasionados pelo casamento malfadado fazem-na parte de um mundo histórico, mesmo que ficcionalmente representado.

\section{Representações do papel da esposa em $A$ mulher que fugiu de Sodoma e em Ana Paula}

Em um escorço histórico sobre o amor no contexto brasileiro, Priore assinala a diferença de condições de homem e mulher na esfera do casamento. Mesmo após o Código Civil de 1916, em que se divisam alguns avanços em face da 
legislação anterior, o papel do marido (público) e o da esposa (privado) discrepam sensivelmente. Como regra de comportamento não posta em letra de lei, restava a aceitação desse quadro pela maioria das mulheres.

Era indisfarçável o conformismo da maioria das mulheres diante da condição de sujeição imposta pela lei e pelos costumes: serva do marido e dos filhos, sua única realização aceitável acontecia no lar. Sua família, como já disse uma historiadora [Michelle Perrot], era "ninho e nó" ao mesmo tempo. Ninho, pois proteção contra agressões externas, muro contra a invasão de sua privacidade. Mas nó porque secreta, fechada, exclusiva e palco de incessantes tensões. (Priore, 2005, p. 260)

Da esposa, desejava-se que fosse o que a escritora vitoriana Coventry Patmore certa vez chamou, em um poema seu, de "O anjo do lar" (Patmore, s.d.), que, diferentemente da chamada "mulher dos tempos modernos" — tendente à autonomia e ao questionamento do papel que a sociedade lhe atribuía -, devia ser complacente e bondosa, para "prever, satisfazer e até adivinhar os desejos do marido"; tentando de tudo para manter o casamento, com a demonstração de "paciência para aceitar [...] fraquezas de caráter [do consorte]" (Priore, 2005, p. 268). Esses desvios de comportamento poderiam se caracterizar em uma ampla gama de faltas, que iam da violência doméstica, passando pela esbórnia e pelo vício no jogo e quase sempre desaguavam no adultério. O marido de Lúcia e o de Ana Paula — respectivamente, Mário e Jorge - longe estão de ser modelares. No primeiro, tem-se um homem que, de médico que tudo teria para ser respeitado (nomeada, condição financeira, competência), convive com a escória social carioca, fruto da jogatina. Deixa de cumprir suas funções maritais — sejam afetivas ou financeiras - para afundar-se no endividamento ocasionado pelo vício. Seu mundo é o de agiotas, malandros e mulheres da vida. Em um interregno de dignidade, quando, após a saída de Lúcia de casa, é enviado por seu tio a Paris a fim de fazer estudos de especialização, afasta-se momentaneamente desse universo. Momentaneamente. Logo estará de volta aos braços de uma mulher que não a sua - a frívola e doce Pervanche - e entregue às apostas nas corridas de cavalos em companhias muito pouco recomendáveis. Na primeira etapa de seus pecados, a brasileira, Mário faz sofrer Lúcia, que tenta o que é possível para sustentar um casamento já sem razão de ser. $\mathrm{O}$ marido de Ana Paula, Jorge, também impinge à sua esposa uma desmoralização em todos os níveis. Mais uma vez, está-se diante do que tudo poderia ser — militar de atos heroicos - e acaba vergado pelo peso de um destino mofino.

O jogo era a sua [de Jorge] paixão absorvente; dados, cartas, apostas, combinações engenhosas, tudo servia para saciar a ânsia nevrótica que lhe corroía, desde a pequena infância, a pureza do caráter. Faltava às aulas para ir jogar as cartas, nas tabernas vizinhas, com uns patifórios com os quais acamaradava e que lhe extorquiam, por artes da batota, os pequenos cobres. Com tal escória se iniciou nas torpezas do vício [...]. (Paço d'Arcos, 1974, p. 115) 
Se as fraquezas de caráter de Mário de Montemor são devidas, em grande parte, ao ambiente de excentricidade em que cresceu com sua mãe, a marquesa de Sincorá, Jorge de Melo parece padecer de um desvio nervoso bem à maneira oitocentista. Em dimensão espacial mais restrita que a de seu correspondente brasileiro, o marido de Ana Paula, quando solteiro, também revela uma inclinação ao jogo e a juntar-se aos maus. Uma vez casado, entrega-se à corrupção no trabalho e na vida amorosa; Jorge também é adúltero, e sua amante - Maria da Graça —, quando vê o poço secar por o provedor encontrar-se encarcerado, não hesita em buscar outro homem. Em um dos momentos de maior humilhação em sua jornada, Ana Paula, ao visitar o marido na prisão, depara com Maria da Graça e tem de dar explicações ao inocente Tony:

- O que é que esta senhora queria do paizinho? - perguntou o pequeno à mãe, cheio de curiosidade.

- É a mulher de um oficial amigo do pai.

$O$ garoto quase nem deu tempo à resposta:

- E por que é que a mãezinha lhe não falou? Por que foi?

- Porque a não conhecia - respondeu Ana Paula após breve hesitação. - Mas agora o Tony vai lá para baixo brincar um bocadinho, sim? (Paço d'Arcos, 1974, p. 183)

Muitas são as provas por que a lisboeta terá de passar sem que deixe de fazer o possível para manter sua condição de mulher casada e respeitável. Trata-se de postura, conforme se detalha adiante, que norteará todo o percurso da personagem na narrativa. É caso diverso, também como já se sinalizou, de Lúcia, que, no capítulo 6 (parte 1) de A mulher que fugiu de Sodoma, tem seu ponto de viragem, com um condicionante - a gota d'água que faz transbordar o balde - muito bem demarcado. Justiniano, pai do jornaleiro Segundo Clichê, telefona em busca do médico Mário, afirmando que o filho está mal, à beira da morte. Lúcia "Desligou repentinamente e, muito branca, vestindo-se às pressas, compreendeu num instante onde o marido estava” (Vieira, 2008, p. 106). É noite que sinaliza chuva, e a mulher, com seu espírito maternal, ainda que não tivesse filhos de seu sangue, parte para a morada humilde e vislumbra um quadro desolador, em muito resultante do descumprimento da promessa que o clínico fizera de acompanhar o enfermo (passando quatro dias sem frequentar a casa):

[Lúcia] Ajoelhou-se diante dessa cama de casado e começou a acariciar a testa do Segundo Clichê. Um suor pastoso gotejava dessa fronte pálida onde um cabelo ruço caía em vírgulas. O fatal gargarejo continuava. Os olhos da criança já não tinham brilho, eram foscos, vítreos, com uma mucosidade nos cantos. As asas do nariz palpitavam e a lividez do rosto era impressionante. (Vieira, 2008, p. 107) 
Vieira, ele mesmo médico, faz seu narrador caracterizar em detalhes os sintomas da meningite que vitimará o pobre menino. ${ }^{12}$ Lúcia mostra o porquê de ser admirada pelos que estão à sua volta, assumindo responsabilidades que cabiam ao marido e revelando comiseração pelos desvalidos, por cuja moradia se movimenta sem qualquer pejo. Se as personagens centrais do autor - conforme já se assinalou — são aquelas pertencentes ao topo da pirâmide social, ainda assim há espaço para lamentar o fado de um pobre jornaleiro, como nesta apóstrofe, em que as palavras do narrador parecem sintonizar com o pensamento de Lúcia:

\section{Mesmo após o Código Civil de 1916, em que se divisam alguns avanços em face da legislação anterior, o papel do marido (público) e o da esposa (privado) discrepam sensivelmente}

Pobre Segundo Clichê... Tu, que muita vez dormiste na soleira das casas comerciais do largo do Machado, tonto de sono e de fadiga, com os teus jornais esparramados pelo chão; tu, que, como quarto teu, tinhas apenas esse quarto onde tua mãe passava a ferro; tu que sentias tão bem, depois do teu trabalho, deitado e estirado entre trastes, ferros de engomar, latas, bacias, caixas de papelão, sapatos velhos e roupas alheias; - dormes, agora, sossegado sob essa colcha que cheira a poções e a óleo canforado... (Vieira, 2008, p. 109)

O tom elegíaco da passagem serve muito para salientar a desumanidade de Mário, que, depois do ocorrido, como indicado, terá ainda o desplante de aceitar honorários de Justiniano... Honorários por uma assistência não fornecida. Em um expediente narrativo que ressalta ainda mais os desvios de caráter do homem viciado em jogo, o narrador vem a revelar o que Lúcia já sabia (onde o marido estava):

A galeria dos tipos era sórdida, parecia incrível que existissem no mundo essas caras reunidas, tão repelentemente reais, desde o mulato atrevidaço, que a cada golpe contrário implica com o azar e blasfema, até o velho encanecido, trêmulo, com tiques nos lábios e nas mãos, chupando cigarros murchos, de olhar odiento e fixo, de maneiras relaxadas, e que joga resignadamente longo tempo, mas que, de súbito estrila, faz parar, chama em testemunho vários desconhecidos a propósito da reclamação [...].

\footnotetext{
$\overline{12}$ Vale notar que um dos problemas que mais se assinalam quando se pensa na infância dentro desse horizonte histórico é, precisamente, o da saúde. Em estudo sobre a representação da infância em São Paulo e no Rio de Janeiro entre as décadas de 1930 e 1950, Brites identifica, ao lado do afastamento da pobreza de regiões valorizadas dos grandes centros (resultado de uma identificação entre "pobreza" e "barbárie"), "a mortalidade infantil [como] uma preocupação constante" (Brites, 1999, p. 253 e 256).
} 
De vez em quando, principalmente nos intervalos, há pilhérias, troca de apelidos e lamentações. Mário inspeciona a assistência. A sala é baixa, secretamente antipática, está nublada pela fumaça dos cigarros, e nela há uma atmosfera, como nos bordéis e nas tavernas de ignomínia, em camadas densas. (Vieira, 2008, p. 112)

Na sala de jogo, o médico deixa de sê-lo — isto é, de estar à cabeceira do pequeno Segundo Clichê - para dar azo à sua inclinação reprovável. O ambiente de pobreza digna da casa de Justiniano é contrastado com a pobreza de espírito do covil em que os homens se rebaixam, ambiente hostil e degradante que se transforma na tônica da existência de Mário. ${ }^{13} \mathrm{O}$ espaço, aqui, é o homem, e Lúcia, assim, parece ter plenas razões para abandonar seu lar. Quando o marido retorna, vem o anúncio, dado pela esposa, que, toda molhada pela chuva e com um olhar próprio da loucura, diz:

- Será crível que de fato sejas o monstro que és? Enganando-me, há dias, que ias lá [casa de Justiniano] passar parte da noite para ver - e aí a voz dela tomou um acento de imitação da dele, cruel, quase exata se não fosse demasiado trágica - se surpreendias certos sintomas à vista dos quais combaterias o mal, ias... jogar... jogar... Ela dizia "jogar" com o pavor e o asco de quem pela primeira vez na vida profere uma palavra obscena. (Vieira, 2008, p. 117)

Vãos são os pedidos de perdão de Mário, e Lúcia sai na noite cheia de chuva e de vento. Fora de si, vaga pelas ruas. As famílias de condições olham para o aguaceiro lá fora sem se darem conta de que "talvez estivessem desabando pardieiros com operários e crianças por esses morros e subúrbios, aluindo barreiras sobre favelas [...]" (Vieira, 2008, p. 121), em um Rio de Janeiro desnivelado socialmente. Enfim, Lúcia, com a roupa colada ao corpo, chega à casa de tia Marta, que fica pasmada com o estado da sobrinha.

Então tia Marta, disfarçando já a dor de cabeça, com um arzinho espantado, a beijocou muitas vezes, apertando-lhe o rosto nas mãos, acariciando-a toda, dando uma risadinha nervosa para reprimir a surpresa e a curiosidade.

— Mas que foi que aconteceu? Ele não se emendou?

- Fique tranquila. Apenas resolvi vir morar aqui. Aceita? (Vieira, 2008, p. 126)

\footnotetext{
${ }^{13} \mathrm{O}$ jogo, em um “discurso moralista de teor religioso", estaria entre os "vícios infamantes e desonrosos”. E mais, por se basear em "práticas supersticiosas [...] e contrapor a sorte à providência divina, afigurava-se inquietante em termos econômicos e sociais, abrindo caminho à subversão do que estava previamente definido, em particular, a ordem divina, o lucro autorizado ou a hierarquização social. [...] Através da imprevisibilidade da 'deusa fortuna', um 'sujo operário' pode ganhar um aristocrata, com todas as implicações simbólicas que esse fato acarreta, muito em especial, a eliminação das diferenças sociais" (Vaquinhas, 2011, p. 323). Ainda que direcionada ao contexto português, a reflexão bem se encontra com Mário, cuja convivência - tanto na cena transcrita quanto, depois, no submundo parisiense - dá bem a conta do quadro indicado e, em certa medida, não deixa de reforçar a tendência aristocratizante de Vieira, que rebaixa socialmente seu protagonista por meio de um vício. Nesse caso, aproximar-se da pobreza é fazê-lo no contexto de uma queda moral.
} 
Mário ainda irá atrás da esposa, mas esta, irresoluta, não permite que a tia deixe-o aproximar-se: "Se é Mário, absolutamente não entro em entendimento com ele. Abomino-o" (Vieira, 2008, p. 128). Em certo grau, a decisão e a agência de Lúcia sugerem resposta a uma provocação feita por Perrot. A historiadora francesa, ao tratar do papel das mulheres no contexto dos regimes totalitários na Europa do entreguerras, indaga: "O que são as mulheres: vítimas ou complacentes? Nesse ponto há um debate historiográfico que levanta a questão, essencial, da adesão das mulheres (e mais amplamente de todo ator social) a seu papel" (Perrot, 2012, p. 144). Ora, não será que a aceitação de uma condição dada significa, também, uma cômoda manutenção do status quo? Veja-se que Lúcia, ao abandonar o marido, irá morar com uma parenta nada mais que remediada e, também, trabalhará em casa alheia para garantir o sustento. Embora não demonstre consciência de classe/condição e seu comportamento não seja diretamente motivado por um regime totalitário - sub-repticiamente, pode-se dizer que sim -, a articulação soa justa.

No final do capítulo em análise, Lúcia irá acompanhar o cortejo fúnebre de Segundo Clichê. Os princípios cristãos da mulher parecem valer mais para o auxílio ao próximo - papel que caberia ao médico - que ao sacramento da união com Jorge. Conforme já se disse, ela deixa a casa da tia apenas para ser preceptora da filha de Ana Maria, quando, enfim, descobre-se coagida por seu hospedeiro sensual. Não voltará a viver com o marido e será tarde demais quando souber que Mário, em algum sentido, tentou levar uma vida regrada que o fizesse merecedor da companhia da esposa.

Em face da tumultuosa relação de Lúcia com Mário, a de Ana Paula com Jorge tem um ingrediente adicional: a inclinação da esposa a outro homem, no caso o advogado e professor Eduardo Reis. Jorge, como se indicou, é encarcerado em decorrência de desfalque cometido na função militar. Seu defensor é, precisamente, Eduardo, homem que se pode ver como o inverso de seu cliente: o advogado é íntegro e aparenta respeitar profundamente Ana Paula. Para esta, assim - e diferentemente de Lúcia -, parece não existir a opção de ficar só. Permanecer ao lado do marido criminoso significa repelir o assédio contido de Eduardo; abandonar o "déspota caseiro" (Paço d'Arcos, 1974, p. 125) corresponde a divorciar-se, após o que viria a união a Eduardo, que Ana Paula, efetivamente, ama. O capítulo em apreço - 6 (parte 2), intitulado "Entre dois suplícios" - mostra, precisamente, a encruzilhada de uma mulher posta entre as humilhações de um casamento em ruínas (com a culpa recaindo integralmente sobre o caráter réprobo do marido) e as promessas de um amor redentor; no meio do caminho, o drama moral gerado pelo eventual descumprimento do contrato matrimonial.

Conforme já foi revelado, a discussão em torno do divórcio, no romance de Paço d'Arcos, faz-se tanto direta - por meio de palavras do narrador, ou de conversações entre personagens - quanto indiretamente, na angústia que envolve os protagonistas da narrativa. O mundo representado em Ana Paula ainda é aquele sob o impacto do pacote legal aprovado pelo advento da República portuguesa, em 1910 - processo, inclusive, que é contemplado expressamente 
pelo autor (cf. Paço d'Arcos, 1974, p. 102-103). Nessas amplas reformas, são instituídos o divórcio e o casamento civil obrigatório, que, segundo Anália Cardoso Torres, "Tratava-se, por um lado, do alargamento dos direitos e liberdades individuais dos cidadãos e, por outro, da separação clara entre Igreja e Estado" (Torres, 1996, p. 31). Antecedida por um fervilhar ideológico e jurídico, a implantação do divórcio em Portugal traz muitos avanços - considerando-se, até mesmo, a conjuntura dos demais países europeus -, pois previa a:

[...] possibilidade do divórcio por mútuo consentimento. Mas é também notória a preservação da garantia da igualdade entre homens e mulheres perante a lei, que se exprime na enumeração dos fundamentos do divórcio, em tudo idênticas para ambos os sexos. (Torres, 1996, p. 32)

Para tal, mostrou-se nítida a influência das primeiras feministas portuguesas, como é o caso de Ana de Castro Osório e de Lucinda Tavares, que, por meio de periódicos, tentam caracterizar o papel social da nova mulher, que seria autônoma e que poderia escolher que função profissional desenvolver. ${ }^{14}$ Essa evolução, no entanto, parece ter um estatuto superficial, de aparência. Prova disso é que, mesmo com a implantação da lei, poucos divórcios se verificaram em Portugal nas duas primeiras repúblicas, sinal claro de que constrangimentos religioso-sociais continuavam a tolher a liberdade feminina no que diz respeito ao casamento (mas não apenas). Veja-se o relato de Irene Vaquinhas:

Os preconceitos religiosos e, a partir da década de 1930, o caráter conservador do regime político [o Estado Novo salazarista] remetiam para as fronteiras da transgressão o divórcio, definido como "viuvez civil" por um autor católico, M. Abúndio da Silva. As divorciadas eram ostracizadas pela opinião pública, alinhada pelas posições tradicionais da Igreja nesta matéria. (Vaquinhas, 2011, p. 150)

A situação íntima vivenciada pela personagem Ana Paula, conforme perceptível na análise que segue, dá muito bem a dimensão de que não é uma intervenção do Estado que irá, de um momento para o outro, modificar diretamente mentalidades formuladas no indivíduo quando de sua formação.

No capítulo em análise, Ana Paula está a caminho do bairro da Encarnação com o fito de visitar uma prima, recolhida no convento. Casualmente, encontra-se com Eduardo, que a interpela.

\footnotetext{
${ }^{14}$ Ana de Castro Osório escreveu: "A lei do divórcio é necessária não para separar os que estão separados e sem escrúpulos seguem o seu destino, mas para libertar os que estão presos dando-lhes a faculdade de procurar a felicidade onde a encontrarem e, sobretudo, para garantir aos filhos a proteção da lei" (Osório apud Torres, 1996, p. 32). Lucinda Tavares, por seu turno, propôs três fatores norteadores do feminismo: "10 Educar a mulher em princípios de liberdade e independência, para que ela eduque seus filhos sob esse sagrado lema. $2^{\circ}$ Conquistar-Ihe os direitos a que tem jus, porque não pode haver a nítida compreensão de dever sem usufruição de direito. $3^{\circ}$ Dadas as razões de ordem econômica com que temos de lutar, que seja lícito à mulher, como o é ao homem, escolher entre os ramos da atividade humana, no extenso e variadíssimo campo do comércio, da ciência, das artes e das letras, aquele por que optar o seu espírito, a sua inteligência, as suas tendências naturais" (Tavares apud Esteves, 2001, p. 95).
} 
A voz tão sua conhecida, Ana Paula voltou-se, confundida como

colegial que tentara escapulir-se, pois logo que vira o carro receara o encontro e quisera, naqueles curtos segundos, ver se ainda lhe fugia, porque por demais sabia o quanto o desejava. Voltou-se e ficou imóvel, à espera que se acercasse. (Paço d'Arcos, 1974, p. 188)

Preocupada com aparências - seu papel de mulher casada em uma Lisboa ainda longe do estatuto de cosmopolita - , Ana Paula recusará atender ao convite de sentar-se com Eduardo para conversar: “- [...] Olhe que seria bonito se passasse alguém conhecido e nos via sentados no jardim; nem você é estudante, nem eu sou costureira"; ao que o advogado retruca: “- Não sei que mal teria. Vocês, meninas de Lisboa, são duma falta de naturalidade constrangedora" (Paço d'Arcos, 1974, p. 188). Insista-se em que o pudor de Ana Paula se deve, sobretudo, à possibilidade de algum passante vir o colóquio; o problema central é sua face diante dos outros, e não as convicções próprias. E Eduardo, por seu turno, insere a amiga em uma categoria, estendendo o comportamento de Ana Paula ao das "meninas de Lisboa”. Maria Helena Santana e António Apolinário Lourenço tocam nas relações públicas entre homem e mulher no Portugal dos primeiros decênios do século XX. A partir de André Brun, cronista da década de 1930, percebem que

[...] a maioria dos pais burgueses tem como preocupação central "arrumar" as filhas, e todas as oportunidades servem para facilitar os encontros, desde as soirées familiares aos lugares públicos: "Em Portugal não se namora apenas da janela abaixo. Namora-se nos jardins, nos passeios, nos cinemas, nas festas familiares, no teatro, em toda a parte, enfim." Não seria bem assim a realidade da época, no que respeita à liberdade dos namorados. É um fato que a diversificação dos espaços de convivência, bem como o acesso generalizado a eles, permitiram a muitos jovens alargar a sua esfera de relações e desfrutálas com menos inibições. Mas o decoro burguês continuava a impor limites apertados à intimidade antenupcial [...]. (Santana e Lourenço, 2011, p. 259-260)

Casada, Ana Paula temia comportar-se como jovem inconsequente e casadoira. Se, em classes mais altas - a que ela pertencia - , o flerte e os passeios são vistos como de bom-tom quando se trata de jovens namorados (Santana e Lourenço, 2011, p. 260), à mãe de família, independentemente de sua condição social, seria vedado sentar-se, em ambiente público, com um homem que não o marido.

Na conversação, travada enquanto Ana Paula e Eduardo caminham pelo passeio, o advogado enfatiza as qualidades da mulher que nele desperta tantos sentimentos, destacando o heroísmo de seus procedimentos diante das várias vicissitudes geradas pela convivência com Jorge. A fala do narrador prepara a intervenção dos caracteres: 
E [Eduardo] não soube o que pensar daquela mulher, que já não amava o marido, desprezada, enxovalhada na sua missão mais nobre, a que a levava todos os dias a Oeiras [onde Jorge está encarcerado], e mesmo assim apegada ao restrito dever, teimosa na sua ideia e dedicada à defesa de quem a desgraçara como se na alma não lhe coubessem outros sentimentos diferentes daquela triste servidão! E teve um comentário:

- Você é heroica, Ana Paula!

- Heroica em quê? Que heroísmo há em cumprirmos o nosso dever?... dever tão comezinho. (Paço d'Arcos, 1974, p. 189)

\section{O mundo representado em Ana Paula ainda é aquele sob o impacto do pacote legal aprovado pelo advento da República portuguesa, em 1910}

Em especificidade, o que condiciona o juízo de Eduardo é o encontro entre Ana Paula e Maria da Graça - sobre que já se comentou - e a permanente impavidez da esposa de Jorge. O que Ana Paula reforça, ao minimizar a grandeza de sua postura ante as provações a que é exposta, é a tentativa de suprimir o sentimento que nutre pelo defensor do marido. A ideia de que deve desempenhar um papel social - com todos os percalços que isso possa significar é a norteadora de seu percurso; assim, a personagem tolhe qualquer lampejo de revolta que se pudesse vislumbrar em seu íntimo. Eduardo, conhecedor de todo o sofrimento de que Ana Paula padece na vida particular, revela o que sente por ela. $\mathrm{O}$ narrador penetra a mente da atormentada mulher e tira-lhe um instantâneo:

Ana Paula ouvira o advogado sem o interromper; empalidecera mortalmente e nunca ele a vira tão bonita como nesse instante em que só a mancha dos lábios carminados escapava à palidez marfínica da formosíssima tez. As palavras de Eduardo vinham de muito longe, duma inalcançável região de sonho de que a separavam todas as chamas do inferno. Vinham de muito longe e traziam na entoação satânica a crudelíssima marca do pecado em que ela tombava, só de ouvi-las! E todavia, ali segredadas pelo ente estremecido, que bálsamo representavam para a sua alma ressequida por todas as amarguras! (Paço d'Arcos, 1974, p. 190)

Forte, a passagem descreve o estado de alma de uma mulher colocada entre seus impulsos mais naturais e o papel social que lhe é atribuído e que ela parece aceitar em silêncio. Por isso, recorre "[...] a toda a força da sua dignidade para se não afastar da posição que a honra senhoril lhe impunha" (Paço 
d'Arcos, 1974, p. 191). A honra, para ela, parece não se caracterizar como um sentimento individual e inerente; talvez tal marca se firme na fortaleza da personagem ao renegar os anseios pessoais. Social, isto sim, parece ser o conceito de honra em pauta, no caso de se honrar um compromisso institucional, qual seja, o do casamento com um homem que já não se mostra digno do preito firmado. Ora, "as jovens esposas eram desde cedo educadas a aceitar sem dramatismos os deslizes naturais dos parceiros" (Santana e Lourenço, 2011, p. 268). E é na formação cristã, assim, que Ana Paula buscará força para seguir em frente em sua resistência:

Só a fé a amparava na sua atribulação, mas se por um lado a amparava, por outro maior angústia ainda lhe trazia, por ser exatamente do fervor da sua fé católica que brotavam os escrúpulos de consciência, a convicção do pecado e o remorso, essa chaga aberta na sua alma e que lentamente a consumia. [...] Lutara quanto pudera e quanto mais se debatera mais se afundara, até àquelas últimas semanas em que, por ter deixado de o [Eduardo] ver, supusera possível a cura e hora a hora verificara o agravamento do mal. Assim pensava; e o amor que lhe transformara os sentimentos não lhe obliterava a razão. [...] Não fora o seu caráter, a obediência à sua fé e a submissão ao destino, não teria respondido a Eduardo com a firmeza com que o fizera, pois que tudo em si, desde a secura dos lábios ao palpitar do coração e ao frêmito dos seios, implorava, exigia a ventura daquele amor. (Paço d'Arcos, 1974, p. 192)

Da mesma forma que o advogado Eduardo luta entre os desígnios da profissão e o sentimento que nutre pela mulher do cliente, Ana Paula trava pesada batalha interna, nos conflitos gerados pelo papel social que lhe é atribuído (e que a própria personagem absorve) e de sua inclinação natural, de busca de uma felicidade de que não se acha digna. Em tom de crítica, o narrador reflete sobre a condição do homem e da mulher na sociedade por que se movimentam as personagens, tentando detectar tanto os papéis que cabe a um e a outra desempenhar quanto os valores que parecem inalienáveis a cada sexo.

O homem pode amar, sofrer, ser desprezado, mas tem sempre voz para clamar suas desditas, beijos venais que lhe acalmem a fronte inquieta, corpos de empréstimo em que enganar sua ansiedade. A mulher é um ser diferente, pelo mundo agravada essa diferenciação. $\mathrm{O}$ amor infeliz é nela longo e silencioso suplício; não tem recursos exteriores a aligeirar-lhe a pena e esta só minora com o tempo, depois de se ter alimentado com a própria essência da alma, imolada assim ao mal que a corrói em vez de empenhada em o combater. Ana Paula sofria em silêncio a dor maior da sua vida de mulher, porque era a primeira vez que sofria sem esperança; esperança neste seu caso seria a consumação do pecado. "Não nos deixeis, Senhor, cair em tentação: mas livrainos do mal. Amém”. (Paço d'Arcos, 1974, p. 193) 
Se o homem, haja vista sua face pública, pode encontrar, em braços que não os da esposa, a saciedade de seus desejos, à mulher não resta nada senão a corrosão interna. Por mais que o Estado português tenha fixado leis que atestassem a igualdade entre homens e mulheres, na práxis social - é o que o romance sugere - está-se diante de quadro diverso, em que o homem tudo pode e à mulher cabe ser o esteio do marido, ainda que indigno, ainda que ausente. A mulher sofre resilientemente, tendo por único apoio uma fé que consiste, de certa maneira, na raiz de seus males - o constrangimento de uma educação religiosa rígida faz da esposa um indivíduo tolhido em suas inclinações mais legítimas. Isso parece resultar, em certa medida, do que Santana e Lourenço chamam da "subcultura do marialvismo", em que o homem pode (e deve) vangloriar-se de suas conquistas amorosas, ao passo que às mulheres caberia reprimir o desejo (Santana e Lourenço, 2011, p. 268).

\section{Por mais que o Estado português tenha fixado leis que atestassem a igualdade entre homens e mulheres, na práxis social - é o que o romance sugere - está-se diante de quadro diverso}

Como que para coroar as faltas cometidas por Jorge, ele, abandonado por Maria da Graça, assedia carnalmente a própria esposa em visita que ela faz ao cárcere. Ana Paula, resistente à corrupção suprema, "Era uma pobre mulher exausta pelo esforço sobre-humano que despendera e amarfanhada pela luta interior de múltiplos sentimentos que lhe esfrangalhavam a alma" (Paço d'Arcos, 1974, p. 197). São-lhe negados os desejos da carne, pois, impedida por circunstâncias de divorciar-se e entregar-se ao homem que verdadeiramente ama, não é, ainda, nos braços do marido iníquo que irá satisfazer-se. A vida parcelar que irá levar o é tanto no que diz respeito ao espírito, impossível de se cultivar quando as obrigações sociais se sobrepõem às individuais, quanto ao sexo. $\mathrm{O}$ ambiente hostil à liberdade feminina mostra-se ainda mais duro na medida em que, tornado em interno pela mulher, guia-lhe cegamente para a autoanulação.

\section{Epílogo}

Se não cabe rechaçar o potencial do discurso ficcional de reconstituir dada conjuntura histórica - independentemente, insiste-se, de a representação realista de um quadro social ser fulcral no projeto do artista - , por outro lado não se pode desprezar o fato de que a ficção sempre significará uma transfiguração manifesta dessa conjuntura, haja vista a reformulação que o autor promove por meio do imaginário. Nesse sentido, a investigação da realidade histórica tendo 
por fonte capital o romance cobra do analista reservas tanto em seu percurso quanto nos resultados que alcança. A ficção não é um relato, $a$ priori, do que se tem por realidade, mas, por lhe ser impossível excluir o mundo à volta do artista - dado que a linguagem empregada para construir o mundo é a mesma que se usa no discurso ficcional - , apresenta muitos aspectos relevantes de como funcionam as relações humanas tanto do plano temporal representado quanto, ainda mais, do plano temporal em que se representa (isto é, a conjuntura da própria produção ficcional).

Reforçado esse estatuto do liame que, indefectivelmente, relaciona o romance com a história, pode-se, sem favor, entender a medida em que $A$ mulher que fugiu de Sodoma e Ana Paula consistem em fontes de conhecimento acerca da condição da mulher casada na década de 1930 no Brasil e em Portugal. Idiossincrasias patentes nesses discursos há várias, sendo possível indicar, em um primeiro nível, a filtragem realizada pela individualidades produtoras (os autores), que, a partir de seu conhecimento de mundo, compuseram narrativas filiadas ao modo realista; e, no nível ficcional, a das mulheres personagens, que, diante de quadros com um quê de aparentados — maridos indignos que submergem moral e socialmente - , assumem comportamentos distintos: o abandono do lar por Lúcia contrasta muito claramente com a resignação cega de Ana Paula. Esta última dimensão, assim, parece consistir em uma resposta típica da literatura, que, mesmo promovendo a ampla representação de uma conjuntura histórica, referenda uma dimensão humanista segundo a qual as particularidades individuais não são obnubiladas pela esfera social.

De outro lado, quando contraposto ao discurso histórico, o literário mostra em que medida a representação ficcional se pode alhear a padrões detectáveis na realidade - seja para referendá-los, seja para questioná-los. Nos dois romances, é possível encontrar diversas marcas que revelam a sociedade representada no que diz respeito à formação das personagens, aos papéis reservados a homens e a mulheres, à estrutura do casamento e à (im)possibilidade da separação e, mais amplamente pensando, aos constrangimentos por que tende a passar a mulher, dos dois lados do Atlântico, na década de 1930.

Dando conta de situações particulares desenvolvidas em um plano socialmente amplo, Vieira e Paço d'Arcos, em vez de reduzirem a significância e a representatividade do mundo representado, acabam enriquecendo o escopo tanto da literatura quanto, por que não dizer, da própria dimensão histórica, pois é nas peculiaridades detectáveis entre a forma de o homem se relacionar com o meio que, em efetivo, conhece-se um tempo. Seja em um discurso sobre a realidade, seja em um discurso ficcional. 


\section{Referências bibliográficas}

AUERBACH, Erich. Mimesis: a representação da realidade na literatura ocidental. 2. ed. São Paulo: Perspectiva, 1976.

BALZAC, Honoré de. Prefácio. In: . A comédia humana. 2. ed. Rio de Janeiro: Globo, 1949. v. 1, p. 10-22.

BARREIRO, José Maria Viqueira. Joaquim Paço d'Arcos: un escritor portugués del siglo XX. Madri: Cultura Hispanica, 1958.

BOSI, Alfredo. História concisa da literatura brasileira. 32. ed. São Paulo: Cultrix, 1995.

BRITES, Olga. Imagens da infância: São Paulo e Rio de Janeiro, 1930/1950. Projeto História, São Paulo, n. 19, p. 251-264, nov. 1999.

BUENO, Luís. Uma história do romance de 30. São Paulo: Universidade de São Paulo; Campinas: Unicamp, 2006.

CANDIDO, Antonio. Brigada ligeira. 4. ed. Rio de Janeiro: Ouro sobre Azul, 2011.

CANEZIN, Claudete Carvalho. A mulher e o casamento: da submissão à emancipação. Revisa Jurídica Cesumar, Maringá, v. 4, n. 1, p. 143-156, 2004.

CHARTIER, Roger. O passado no presente: ficção, história e memória. In: ROCHA, João Cezar de Castro (Org.). Roger Chartier: a força das representações: história e ficção. Chapecó: Argos, 2011. p. 95-124.

ESTEVES, João. Os primórdios do feminismo em Portugal: a la década do século XX. Penélope, Lisboa, n. 25, p. 87-112, 2001.

FOWLER, Alastair. Las dos historias. In: BELTRÁN ALMERÍA, Luis; ESCRIG, José Antonio (Org.). Teorías de la historia literaria. Madri: Arcos, 2005. p. 253-272.

MENDES, Óscar. A alma dos livros: um brasileiro lê Paço d Arcos. Lisboa: Parceria A. M. Pereira, 1972.

MOURA, Maria Lúcia de Brito. Sensibilidade religiosa e devoção doméstica: entre o "temor de Deus" e o "amor de Deus". In: VAQUINHAS, Irene (Coord.). História da vida privada em Portugal: a época contemporânea. Lisboa: Círculo de Leitores, 2011. p. 290-321.

PAÇO D'ARCOS, Joaquim. Ana Paula. Rio de Janeiro: José Aguilar, 1974.

PATMORE, Coventry. The angel in the house. [s.d.]. Disponível em: <http://www.victorianweb. org/authors/patmore/angel/>. Acesso em: 12 out. 2012.

PERROT, Michelle. Minha história das mulheres. 2. ed. São Paulo: Contexto, 2012.

PRIORE, Mary del. História do amor no Brasil. São Paulo: Contexto, 2005.

REIS, José Carlos. História \& teoria: historicismo, modernidade, temporalidade e verdade. 3. ed. Rio de Janeiro: FGV, 2006.

SANTANA, Maria Helena; LOURENÇO, António Apolinário. No leito. Comportamentos sexuais e erotismo. In: VAQUINHAS, Irene (Coord.). História da vida privada em Portugal: a época contemporânea. Lisboa: Círculo de Leitores, 2011. p. 254-289.

SPINA, Segismundo. Introdução à edótica. São Paulo: Cultrix/Universidade de São Paulo, 1977. TORRES, Anália Cardoso. Divórcio em Portugal: ditos e interditos: uma análise sociológica. Oeiras: Celta, 1996.

VAQUINHAS, Irene. Paixões funestas e prazeres proibidos. In: (Coord.). História da vida privada em Portugal: a época contemporânea. Lisboa: Círculo de Leitores, 2011. p. 322-351. VIEIRA, José Geraldo. A mulher que fugiu de Sodoma. Belo Horizonte: Leitura, 2008. WHITE, Hayden. A questão da narrativa na teoria histórica contemporânea. In: NOVAIS, Fernando A.; SILVA, Rogério F. da (Org.). Nova história em perspectiva. São Paulo: Cosac Naify, 2011. v. 1, p. 438-483.

WHITE, Hayden. La historia literaria de Auerbach: causalidad figural e historicismo modernista. In: ALMERÍA, Luis Beltrán; ESCRIG, José Antonio (Org.). Teorías de la historia literaria. Madrid: Arcos, 2005. p. 301-326. 